\title{
IMPORTANCE OF ZINC CONCENTRATION IN SEMINAL FLUID OF MEN DIAGNOSED WITH INFERTILITY
}

\author{
Andrea Milostić-Srb ${ }^{1}$, Aleksandar Včev ${ }^{1,2}$, Marijan Tandara $^{3}$, Svjetlana Marić ${ }^{1}$ \\ Vesna Kuić-Vadlja ${ }^{4}$, Nika Srb ${ }^{2}$ and Dubravka Holik ${ }^{2}$
}

${ }^{1}$ Osijek Faculty of Dental Medicine and Health, Josip Juraj Strossmayer University of Osijek, Osijek, Croatia;

${ }^{2}$ Osijek Faculty of Medicine, Josip Juraj Strossmayer University of Osijek, Osijek, Croatia; ${ }^{3}$ Šparac Polyclinic of Obstetrics and Gynecology, Split, Croatia; ${ }^{4}$ Osijek University Hospital Centre, Osijek, Croatia

SUMMARY - The prevalence and importance of male infertility make it a serious worldwide medical and social problem. The aim of this study was to determine if there were any significant differences in zinc concentrations in seminal fluid in men diagnosed with infertility compared to control group, and if there were, to determine how it affected the number and percentage of sperm cells with normal motility and morphology. A case-control study was conducted in the Osijek-Baranja County from January 2014 to June of 2015 . The study included 276 subjects referred to biochemistry laboratory of the Osijek University Hospital Centre, 100 (36.2\%) of them with low sperm count confirmed by spermiogram after 3 months. Semen samples were processed according to the World Health Organization criteria, and zinc concentrations were determined using spectrophotometry and direct colorimetry without deproteinization on a chemistry analyzer (Olympus AU 680, Beckman Coulter, Tokyo, Japan). Study results showed the men with low sperm count to be significantly older (Mann Whitney $U$ test: $p=0.013)$ and to have lower zinc levels $\left(\chi^{2}\right.$-test: $\left.p<0.001\right)$. Further analysis included $100(36.2 \%)$ patients with low sperm count. In the group of infertile men, those with low sperm count had higher zinc levels compared to men with azoospermia (Mann Whitney $U$ test: $p=0.036$ ), suggesting a connection between lower zinc level in seminal fluid and male fertility. Zinc as a biological marker and an antioxidant affects sperm count, motility and morphology. Zinc supplemental therapy could improve seminal parameters in patients diagnosed with low sperm count. Dietary habits of the subjects differ regionally, and future research could make a solid foundation for complementary approach to treatment of male infertility.

Key words: Croatia; Infertility, male; Zinc; Case-control studies; Oligospermia; Semen

\section{Introduction}

According to the World Health Organization (WHO), infertility is defined as the inability to spontaneously conceive during one year of normal sexual activity without the usage of contraception, and demo-

Correspondence to: Assist. Prof. Dubravka Holik, $M D, M S$, Osijek Faculty of Medicine, Josip Juraj Strossmayer University of Osijek, Josipa Huttlera 4, HR-31000 Osijek, Croatia

E-mail:dholik@mefos.hr

Received July 3, 2018, accepted May 23, 2019 graphic data show increase in the infertility rate in the most developed countries ${ }^{1}$. In western countries, $15 \%$ of couples are not able to conceive during one year (48.5 million couples), with male infertility as the cause identified in $60 \%$ and female infertility in $40 \%$ of cases. The increase of infertility is an important factor in demographic transition and imbalance, thus it significantly contributes to depopulation and is becoming one of the leading public health problems faced by more and more couples ${ }^{2}$. Experts agree that the etiology of infertility is multifactorial, with enormous influence of stress, smoking, alcoholism, obesi- 
ty ${ }^{3,4}$, too much physical activity, exposure to toxins, radiation and high temperatures ${ }^{5}$. Alongside these factors, mechanical and reversible damages such as varicocele cause $25 \%-40 \%$ of cases of infertility. In $20 \%$ $30 \%$ of the cases, it is not possible to determine the etiology, and this kind of infertility is referred to as idiopathic ${ }^{6}$. When male infertility is suspected, one of the first procedures to be used is seminal fluid analysis. This procedure is simple and noninvasive while providing the necessary information for establishing the initial diagnosis. Semen analysis reveals complete absence of sperm cells (azoospermia), decreased number of sperm cells (oligozoospermia), decreased sperm motility (asthenozoospermia), or abnormal morphology (teratozoospermia). Motility, structure, sperm concentration, and the components of semen are extremely important for normal sperm function ${ }^{1}$. By determining the biochemical components of semen (fructose, phosphatase, citric acid, zinc), using microbiological analysis, determining sperm antibodies and biological markers we get better view into reproductive health and fertility of the male partner ${ }^{7}$. Microelements are a group of important factors in maintaining the normal function, structure, motility and sperm count $^{8}$. A few studies have shown how zinc has an antioxidative and anti-inflammatory effect ${ }^{9}$, and participates in producing antioxidative enzymes important for cell protection ${ }^{10}$. The amount of zinc in the human body is relatively constant; it makes up to $24 \%$ of all trace elements. Most of it is found in the prostate (100 times more than in blood) and is evenly distributed in the kidneys, liver, muscles and heart, but in some body fluids its concentration is variable ${ }^{11}$. Zinc level in seminal fluid is related to sperm concentration and motility $^{12}$. The lack of zinc leads to many different symptoms, so low zinc concentration affects sperm quality and male fertility ${ }^{13}$. Sperm cells are extremely sensitive to damages caused by oxidative stress because of the large amounts of unsaturated fatty acids in their membranes that are essential for sperm capacitation, acrosome reaction and sperm/oocyte interaction. During lipid peroxidation, sperms lose their membrane integrity, which leads to inactivation of inner cell enzymes, structural DNA damages and apoptosis. Lipid peroxidation of sperm membranes is considered to be the main mechanism of reactive oxygen species (ROS)induced sperm damage that leads to infertility ${ }^{14}$. The number and motility of sperm decreases due to changes in sperm DNA, thus increasing the number of mor- phologically abnormal sperm cells, which leads to a decreased ability of penetrating the oocyte and lower chances of insemination ${ }^{15,16}$. The role of oxidative stress in male infertility has been significantly scientifically supported and evaluation of zinc deficiency could play a key role in diagnosing the cause of sperm damage.

The aim of this study was to determine if there were any significant differences in zinc concentrations in seminal fluid in men diagnosed with infertility as compared to control group, and if there were, to determine how it affected the number and percentage of sperm cells of normal motility and morphology.

\section{Subjects and methods}

\section{Study design}

A case-control study was conducted in the OsijekBaranja County from January 2014 to June of 2015. Study subjects were referred to the Osijek University Hospital Centre by their general practitioner. Semen samples were analyzed by routine procedure at the Andrology and Biochemistry Laboratory, Osijek University Hospital Centre. The study protocol was approved by the Ethics Committee of the Osijek Faculty of Medicine (code: 2158-61-07-15-104).

\section{Study participants}

The study included 276 men, 100 (36.2\%) of them diagnosed with low sperm count and 176 (63.8\%) with normal spermiogram according to the $2010 \mathrm{WHO}$ guidelines. Out of 100 subjects diagnosed with low sperm count, 26 had azoospermia. The including criteria were as follows: routine examinaton of the male partner of the infertile couple, inability to concieve during one year of intercourse without protection, age over 18, and at least two semen analyses. The excluding criteria were age $<18$ years, varicocele, prostatitis, and malignant disease. The subjects were informed on the way of preparing and obtaining the sample. The samples were obtained by masturbating into a small container, and the sampling was done after minimally 2-5 days of sexual abstinence. For this research, demographic data (age, place of residence) were used and the values of seminal parameters (zinc concentration, motility, morphology and sperm count) were established. 


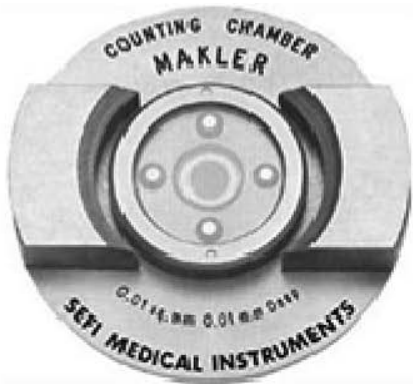

a)

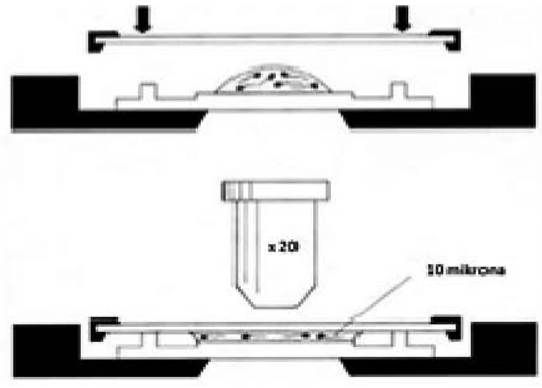

b)

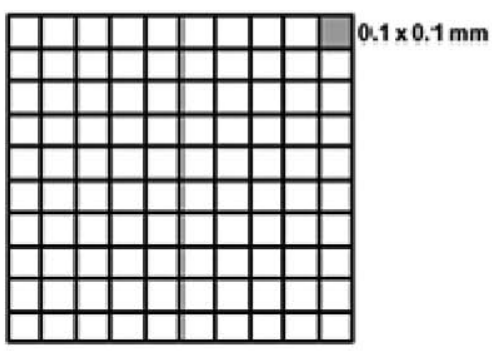

c)

Fig. 1. (a) Makler chamber; (b) scheme of the chamber; (c) net for sperm counting. (source: http://www.sefimedical.com/images/makler_chamber_shema.gif; accessed on July 11, 2013).

\section{Methods}

\section{Determining zinc concentrations}

Zinc concentrations were determined by atomic absorption spectroscopy (AAS) at the Department of Clinical Laboratory Diagnosis, Osijek University Hospital Centre. The sperm obtained by centrifugation was processed for 10 minutes at $2000 \mathrm{rpm}$. The supernatant was diluted by adding distilled water (1:21) and zinc concentration was determined on an Olympus AU 680 autoanalyzer (Beckman Coulter, Tokyo, Japan). Zinc levels were measured in $\mathrm{mmol} / \mathrm{L}$ (reference interval: $1.2-3.5 \mathrm{mmol} / \mathrm{L}$ ).

\section{Determining sperm count, motility and morphology}

The concentration of sperm cells was determined in a Makler chamber. If the sperm count was lower than $15 \times 10^{6} / \mathrm{mL}$ (oligozoospermia), or if there was complete absence of sperm cells (azoospermia), it indicated infertility. A small drop of the sample was stirred up with a glass rod, put in the center of the chamber and covered. The cells were counted under a magnification of X20 in 10 squares, and the sum corresponded to the concentration measured in $\mathrm{mmol} / \mathrm{L}$ (Fig. 1).

Sperm motility in a sample was determined under magnification of X400 on a Nikon YS 2-t (168159) phase contrast microscope (Nikon, Japan). Sperm cell morphology was determined by the Pap test. The whole sperm cell was observed, its shape and size of its head, neck and tail, and the relationship between them. The method allows coloring the acrosomal and postacrosomal parts of the head and tail, as well as distinguishing the basophilic and acidophilic components, thus enabling good look at nuclear chromatin. The share of morphologically normal sperm cells cannot be less than $4 \%$. If there are no sperm cells found in the sample, the whole sample is centrifuged and the sediment is examined to determine cryptozoospermia or azoospermia.

\section{Statistics}

Categorical variables were expressed as absolute and relative frequencies. Numerical data were described using arithmetic mean and standard deviation for normal data distribution, and median and interquartile range for the remaining cases. Differences in categorical variables were tested using the $\chi^{2}$-test and the Fisher exact test if necessary. The KolmogorovSmirnov test was used to test normal data distribution. Differences in normally distributed numerical variables between two independent groups were tested using Student's t-test, and by Mann-Whitney $U$ test in case of deviation from normal distribution. All $p$ values were two-tailed. The significance of differences determined by statistical testing was expressed at the level $\mathrm{p}<0.05$. The statistical software package Statistica for Windows 2010 (version 10.0, StatSoft Inc., Tulsa, OK, USA) was used for data analysis ${ }^{17}$.

\section{Results}

The research was conducted on 276 men, out of which 176 (63.8\%) had normal spermiogram, and 100 (36.2\%) had been diagnosed with low sperm count. The subjects with low sperm count subfertility were significantly older (median 35, interquartile range 3138.25) compared to those with normal spermiogram (Mann Whitney U test; $\mathrm{p}=0.013$ ). In the former, me- 
Table 1. Median age, sperm count, mobility, morphology and zinc level in seminal fuid of study subjects

\begin{tabular}{|l|l|l|l|}
\hline \multirow{2}{*}{} & \multicolumn{2}{|c|}{ Median [Q1, Q3] } & \multirow{2}{*}{ p $^{*}$} \\
\cline { 2 - 3 } & $\begin{array}{l}\text { Control group } \\
\mathrm{n}=176\end{array}$ & $\begin{array}{l}\text { Low sperm count } \\
\mathrm{n}=100\end{array}$ & 0.013 \\
\hline Age (years) & $32(30-37.25)$ & $35(31-38.25)$ & $<0.001$ \\
Sperm count $>15 \mathrm{x} 10^{6} / \mathrm{mL}$ & $117(59.75-173)$ & $9(0-19.25)$ & $<0.001$ \\
Motility $>40 \%$ & $63(58-67)$ & $30(0-40)$ & $<0.001$ \\
Morphology $>4 \%$ & $39(34-46)$ & $26.5(0-32)$ & 0.010 \\
Zinc $1.2-3.5 \mathrm{mmol} / \mathrm{L}$ & $1.8(1.3-2.53)$ & $1.55(0.8-2.1)$ & \\
\hline
\end{tabular}

Median [Q1, Q3] interquartile range; *Mann Whitney U test

Table 2. Zinc levels in study subjects

\begin{tabular}{|c|c|c|c|c|}
\hline \multirow{2}{*}{$\begin{array}{l}\text { Zinc level } \\
1.2-3.5 \mathrm{mmol} / \mathrm{L}\end{array}$} & \multicolumn{3}{|c|}{ Number of participants (\%) } & \multirow[b]{2}{*}{$\mathrm{p}^{*}$} \\
\hline & $\begin{array}{l}\text { Control group } \\
\mathrm{n}=176\end{array}$ & $\begin{array}{l}\text { Low sperm count } \\
\mathrm{n}=100\end{array}$ & Total & \\
\hline Lower than reference interval $<1.2$ & $32(18.2)$ & $38(38.0)$ & $70(25.4)$ & \\
\hline Reference interval 1.2-3.5 & $132(75.0)$ & $59(59.0)$ & $191(69.2)$ & $<0.001$ \\
\hline Higher than reference interval & $12(6.8)$ & $3(3.0)$ & $15(5.4)$ & \\
\hline
\end{tabular}

${ }^{*} \chi^{2}$-test

Table 3. Median age and zinc level in the group of men diagnosed with low sperm count

\begin{tabular}{|c|c|c|c|}
\hline & \multicolumn{2}{|c|}{ Median [Q1, Q3] } & \multirow[b]{2}{*}{$\mathrm{p}^{*}$} \\
\hline & $\begin{array}{l}\text { Azoospermia } \\
\mathrm{n}=26\end{array}$ & $\begin{array}{l}\text { Low sperm count } \\
\mathrm{n}=74\end{array}$ & \\
\hline Age & $34(28.75-39.5)$ & $35(31.25-38)$ & 0.880 \\
\hline Zinc & $1.1(0.65-1.6)$ & $1.75(0.9-2.2)$ & 0.036 \\
\hline
\end{tabular}

Median [Q1, Q3] interquartile range; *Mann Whitney U test

dian sperm count was 9 (interquartile range 0-19.25), motility 30\% (interquartile range $0-40$ ), morphology $26.5 \%$ (interquartile range $0-32$ ), all significantly lower compared to men with normal spermiogram analysis (Mann Whitney $U$ test; $p<0.001$ ). Zinc values in the sperm samples of infertile men had a significantly lower median of 1.55 (interquartile range 0.8-2.1) (Mann Whitney U test; $\mathrm{p}=0.010$ ) (Table 1).

After examining the results, the participants were put into 3 groups: lower and higher than the reference interval and the ones in the reference interval. The zinc values lower than the reference were found in $70(25.4 \%)$ of the participants, in the reference interval 191 (69.2\%), and higher than the reference in 15 (5.4\%). Significant- ly more men, 42 (35.9\%), had zinc values lower than the reference ones $\left(\chi^{2}\right.$ test, $\left.\mathrm{p}<0.001\right)$ (Table 2$)$.

In the group of infertile men, those with low sperm count had significantly higher median zinc level of 1.75 (interquartile rage $0.9-2.2$ ) compared to those with azoospermia (Mann Whitney U test; $\mathrm{p}=0.036$ ) (Table 3).

\section{Discussion}

This research confirmed the correlation between zinc level and infertility in men diagnosed with infertility in the sample population.

Zinc is an essential oligoelement necessary for a great number of metabolic processes of over 300 metalloenzymes and more than 500 regulatory protein genes, and is involved in many enzyme reactions. Zinc concentration is higher in the male reproductive organs and semen compared with other bodily fluids and tissues, thus it affects sperm quality ${ }^{11}$. Zinc value in the sperm of the low sperm count men was $1.55 \mathrm{mmol} / \mathrm{L}$, which was much lower compared to the values recorded in the control group $(1.8 \mathrm{mmol} / \mathrm{L})$. Other studies have reported similar results that point to lower zinc 
levels in the sperm of infertile men ${ }^{13,15,16,18}$. When looking at the study results, it should be taken in consideration that the observed population did not include patients with chronic illnesses, smokers, alcoholics, and those on any medication or vitamin/mineral therapy because of the possible effects on sperm quality. The environmental factors, diet, lifestyle, exposure to heavy metals, radiation and high temperature were not considered either, since several other studies had already associated them to male infertility ${ }^{5}$. In the present study, the low sperm count men were older than 35 , compared with the men with normal spermiogram analysis, who were aged 32 years. Little is still known about the effect of age on infertility; however, a recent study in France done on 8515 couples showed that men over 35 had $50 \%$ less chances of parenthood compared to 25 -year-olds ${ }^{19}$. The reason for this is the longer period of exposure to risk factors that may lead to mutations in the spermatocyte DNA, such as oxidative stress to which men were exposed during their lifetime ${ }^{20}$. Accumulation of toxic heavy metals (lead, mercury, cadmium) in testicular tissue can also affect male fertility as does the low zinc level in sperm cells $^{21}$. Researchers from the University of Newcastle discovered three times more DNA damages in the spermatocytes of men aged 36-57 than in those younger than $35^{22}$. Lifestyle also affects male reproductive health, as well as the global decline in human sperm quality over the past decades. Factors associated with male infertility are smoking, alcohol, drug use, stress, eating habits, as well as excessive drinking of coffee $^{5}$ and obesity that has an epidemic character worldwide, with a $28.8 \%$ to $36.9 \%$ increase between 1980 and $2013^{3}$. In addition, other factors such as exposure of testes to high heat, intense exercise, lack of sleep and exposure to electromagnetic radiation have also been related to infertility 5 . The median sperm count found in the infertile men was $9 \times 10^{6}$, motility $30 \%$ and morphology $26.5 \%$, yielding a statistically enormous difference compared to the control group. Zhao and Xiong proved that there was a connection between low zinc levels in the sperm of infertile men and all the parameters listed above ${ }^{23}$.

According to their zinc levels, study subjects were divided into 3 groups, as follows: lower and higher than the reference interval, and those within the reference interval. Seventy (25.4\%) subjects had zinc levels lower than the reference interval, 191 (69.2\%) were within the reference interval, and 15 (5.4\%) had zinc levels higher than the reference interval. More than 38 (38\%) subjects diagnosed with low sperm count had zinc levels lower than the reference interval, which was consistent with the above-mentioned research. Moreover, 59 (59\%) subjects had zinc levels within the reference interval, whereas only three $(3 \%)$ subjects had zinc levels higher than the reference interval. The lower zinc levels in the control group may point to inflammation and prostatic changes ${ }^{24}$, but this may have been overlooked because health status of the patients was not examined during the research ${ }^{25}$. A few researches have reported that oral zinc supplements improve sperm cell count, mobility and morphology in men with idiopathic infertility, and to some extent also in fertile men diagnosed with asthenozoospermia and/or oligozoospermia ${ }^{25,26}$. In the group of men diagnosed with low sperm count, those who had azoospermia had significantly lower zinc levels $(1.1 \mathrm{mmol} / \mathrm{L}) \mathrm{com}$ pared with the rest of the group $(1.75 \mathrm{mmol} / \mathrm{L})$. These results were consistent with other recent researches ${ }^{27}$, but in contrast with older researches stating that there was no difference in zinc levels between azoospermia patients and those with asthenozoospermia or oligozoospermia ${ }^{28}$. Azoospermia is found in $1 \%$ of the general population and in $10 \%-15 \%$ of infertile men ${ }^{29}$. In the Osijek-Baranja County, its prevalence is $9.4 \%$, which is consistent with the data from the above-mentioned literature.

\section{Conclusion}

The results of the present research point to the importance of zinc in diagnosing male infertility and may help in explaining the etiopathogenesis of the reproductive function of men, thus assisting in therapy and prevention of the disorder in our population. Dietary habits of the subjects differ regionally and future research could provide solid foundation for an additional approach in treating male infertility. Given the fact that this research included men from the Osijek-Baranja County, it may assist in future researches on this subject.

\section{References}

1. WHO Laboratory Manual for the Examination of Human Semen and Sperm-Cervical Mucus Interaction, $5^{\text {th }}$ edn. Pub- 
lished on behalf of the WHO by Cambridge University Press, 2010. http://www.who.iris/handle/10665/44261

2. Hrvatski zdravstveno-statistički ljetopis za 2013 godinu. Hrvatski zavod za javno zdravstvo. Zagreb, 2014. (in Croatian)

3. Kasum M, Anić-Jurica S, Čehić E, Klepac-Pulanić T, Juras J, Žužul K. Influence of male obesity on fertility. Acta Clin Croat. 2016;55:301-8. doi: 10.20471/acc.2016.55.02.18

4. Dupont C, Faure C, Sermondade N, Boubaya M, Eustache F, Clément P. Obesity leads to higher risk of sperm DNA damage in infertile patients. Asian J Androl. 2013;15:622-5. doi: 10.1038/aja.2013.65

5. Durairajanayagam D. Lifestyle causes of male infertility. Arab J Urnal. 2018;16:10-20. doi: 10.1016/j.aju.2017.12.004

6. Kasum M. Idiopatska neplodnost. Gynaecol Perinatol. 2007; 16:181-4. (in Croatian)

7. Šimunić V, et al. Ginekologija. Zagreb: Medicinska biblioteka; 2001. (in Croatian)

8. Massányi P, Trandzik J, Nad P, Koreneková B, Skalická M, Toman R, Lukac N, Halo M, Strapak P. Concentration of copper, iron, zinc, cadmium, lead, and nickel in bull and ram semen and relation to the occurrence of pathological spermatozoa. J Environ Sci Health A Tox Hazard Subst Environ Eng. 2004; 39:3005-14.

9. Marzec-Wróblewska U, Kamiński P, Lakota P. Influence of chemical elements on mammalian spermatozoa. Folia Biol (Praha). 2012;58:7-15.

10. Roohani N, Hurrell R, Kelishadi R, Schulin R. Zinc and its importance for human health: an integrative review. J Res Med Sci. 2013;18(2):144-57.

11. Tus A, Rakipović A, Peretin G, Tomić S, Šikić M. BioMe: biologically relevant metals. Nucleic Acids Res. 2012;40 (Web Server issue): W352-W357. doi: 10.1093/nar/gks514

12. Türk S, Mändar R, Mahlapuu R,Viitak A, Punab M. Male infertility: decreased levels of selenium, zinc and antioxidants. J Trace Elem Med Biol. 2014;28(2):179-85. doi: 10.1016/j. jtemb.2013.12.005

13. Colagar AH, Marzonya ET, Chaichib MJ. Zinc levels in seminal plasma are associated with sperm quality in fertile and infertile men. Nutr Res. 2009;29(2):82-8. doi: 10.1016/j.nutres.2008.11.007

14. Xie D, Lu C, Zhu Y, Zhu S, Yang EJ, Jin X. Analysis on the association between sperm DNA fragmentation index and conventional semen parameters, blood microelements and seminal plasma ROS in male patients with infertility. Exp Ther Med. 2018;15(6):5173-6. doi: 10.3892/etm.2018.6115

15. Yamaguchi S, Miura C, Kikuchi K, Celino FT, Agusa T, Tanabe S, Miura T. Zinc is an essential trace element for spermatogenesis. Proc Natl Acad Sci USA. 2009;106(26):1085964. doi: 10.1073/pnas.0900602106

16. Schulte RT, Ohl DA, Sigman M, Smith GD. Sperm DNA damage in male infertility: etiologies, assays, and outcomes. J
Assist Reprod Genet. 2010;27(1):3-12. doi: 10.1007/s10815009-9359-x

17. Detels R, Gulliford M, Karim QA, Tan CC. Oxford Textbook of Global Public Health. $6^{\text {th }}$ edn. Oxford: Oxford University Press; 2015. Chapter 5, Statistical methods; p. 613-33.

18. Hadwan MH, Almashhedy LA. Oral zinc supplementation restores high molecular weight seminal zinc binding protein to normal value in Iraqi infertile men. BMC Urol. 2012;12:32. doi: 10.1186/1471-2490-12-32

19. Eskenazi B, Wyrobek AJ, Sloter E, Kidd SA, Moore L, Young $\mathrm{S}$, Moore D. The association of age and semen quality in healthy men. Hum Reprod. 2003;18:447-54.

20. Al-Bader A, Omu AE, Dashti H. Chronic cadmium toxicity to sperm of heavy cigarette smokers: immunomodulation by zinc. Arch Androl. 1999;43(2):135-40.

21. Eggert-Kruse W, Zwick EM, Batschulat K, Rohr G, Armbruster FP, Petzoldt D, Strowitzki T. Are zinc levels in seminal plasma associated with seminal leucocytes and other determinations of semen quality? Fertil Steril. 2002;77(2):260-9.

22. Kidd SA, Eskenazi B, Wyrobek AJ. Effects of male age on semen quality and fertility: a review of the literature. Fertil Steril. 2001;75:237-48.

23. Zhao RP, Xiong CL. Zinc content analysis in serum, seminal plasma and spermatozoa of asthenozoospermic and oligoasthenozoospermic patients. Zhonghua Nan Ke Xue. 2005;11: 680-2.

24. Feng P, Li TL, Guan ZX, Franklin RB, Costello LC. Direct effect of zinc on mitochondrial apoptogenesis in prostate cells. Prostate. 2002;52:311-8. doi: 10.1002/pros.10128

25. Ebisch IM, Thomas CM, Peters WH, Braat DD, SteegersTheunissen RP. The importance of folate, zinc and antioxidants in the pathogenesis and prevention of subfertility. Hum Reprod Update. 2007;13(2):163-74. doi: 10.1093/humupd/dml054

26. Kumar N, Verma RP, Singh LP, Varshney VP, Dass RS. Effect of different levels and sources of zinc supplementation on quantitative and qualitative semen attributes and serum testosterone level in crossbred cattle (Bos indicus $\mathrm{x}$ Bos taurus) bulls. Reprod Nutr Dev. 2006;46:663-75. doi: 10.1051/rnd:2006041

27. Hassan AMA, El Hadad AF, El-Mohammady AESAH, Shaker OG, Attaby MEH. Estimation of zinc in seminal fluid among infertile men. Eurasian J Educ Res. 2012;1:34-41.

28. Lin YC, Chang TC, Tseng YJ, Lin YL, Huang FJ, Kung FT, Chang SY. Seminal plasma zinc levels and sperm motion characteristics in infertile samples. Chang Gung Med J. 2000; 23:260-6.

29. Male Infertility Best Practice Policy Committee of the American Urological Association; Practice Committee of the American Society for Reproductive Medicine. Report on evaluation of the azoospermic male. Fertil Steril. 2006;86(Suppl 1):210-5. doi: 10.1016/j.fertnstert.2006.08.030 


\section{Sažetak}

\section{ZNAČENJE KONCENTRACIJE CINKA U SJEMENOJ TEKUĆINI KOD MUŠKARACA S DIJAGNOZOM NEPLODNOSTI}

\section{A. Milostić-Srb, A. Vcever, M. Tandara, S. Marić, V. Kuić-Vadlja, N. Srb i D. Holik}

Muška neplodnost s obzirom na njenu učestalost i važnost predstavlja ozbiljan globalni medicinski i socijalni problem. Cilj ovoga istraživanja bio je utvrditi postoje li značajne razlike koncentracije cinka u sjemenoj tekućini muškaraca s dijagnozom smanjene plodnosti u odnosu na kontrolnu skupinu te ako postoje, utvrditi kako razina cinka djeluje na broj, postotak pokretnih i broj morfološki normalnih spermija. Studija slučajeva i kontrola provedena je na području Osječko-baranjske županije u razdoblju od siječnja 2014. godine do lipnja 2015. godine. U studiju je bilo uključeno 276 ispitanika koji su bili upućeni u biokemijski laboratorij KBC-a Osijek, od kojih je kod 100 (36,2\%) ispitanika potvrđena dijagnoza smanjene plodnosti ponovljenim spermogramom nakon 3 mjeseca. Uzorci sjemene tekućine obrađeni su u skladu s kriterijima Svjetske zdravstvene organizacije, a koncentracija cinka određena je spektrofotometrijskom, direktnom kolorimetrijskom metodom bez deproteinizacije na kemijskom analizatoru tipa Olympus AU 680 (Beckman Coulter, Tokyo, Japan). Istraživanje je pokazalo kako su muškarci s dijagnozom smanjene plodnosti značajno stariji (Mann Whitney U test: $p=0,013$ ) i imaju značajno niže vrijednosti cinka $\left(\chi^{2}\right.$-test: $\left.p<0,001\right)$. Vrijednosti cinka bile su značajno više u skupini ispitanika s dijagnozom smanjene plodnosti kod kojih su nađeni spermiji u odnosu na ispitanike kojima je utvrđena azoospermija (Mann Whitneyev $\mathrm{U}$ test: $\mathrm{p}=0,036$ ). Koncentracija cinka kao značajnog biološkog biljega i antioksidansa utječe na broj, pokretljivost i morfologiju spermija. Nadomjesna terapija cinkom mogla bi poboljšati sjemene parametre kod bolesnika s dijagnozom smanjene plodnosti. Prehrambene navike ispitanika regionalno se razlikuju, a buduća istraživanja mogla bi postaviti dobre temelje za komplementarno liječenje muške neplodnosti.

Ključne riječi: Hrvatska; Neplodnost muškarca; Cink; Studija slučajeva i kontrola; Oligospermija; Sperma 